\title{
1814-2014: BICENTENARIO DE LA VERDADERA INDEPENDENCIA PERUANA
}

\author{
EL GRITO LIBERTARIO \\ DESDE LOS ANDES
}

Eleazar Crucinta Ugarte $^{1}$

Es ste nuestro país, debido a una serie de circunstancias, - políticas, sociales, económicas, etc. - se va haciendo cada vez más proclive a la amnesia histórica, porque vive desde hace algún tiempo atrás, su presente sin la necesaria levadura del pasado que fermentó esta nuestra patria, con el verbo repetidamente acción, siguiendo las imborrables huellas José Gabriel Túpac Amaru.

Como bien se sabe, el Cusco siempre fue la capital de las más grandes sublevaciones anticoloniales que se registraron en su greda histórica, para lograr la verdadera independencia del Perú. Síntesis libertaria, que se vislumbra con mayor fuerza con el Movimiento Independentista Americano, liderado por José Gabriel Túpac Amaru, considerado padre de la libertad americana, por su tenaz lucha contra el opresor yugo español, generó la verdadera y real huella digital para la emancipación de nuestro continente americano.

No es nada casual la ilusa afirmación de algunos historiadores, al calificar la épica gesta de José Gabriel Túpac Amaru, "como acción fracasada", ello, con la intención de minimizary negar la

1 Magíster en Historia en la Universidad San Pablo de Arequipa. Magister en Docencia Universitaria en la Universidad Nacional de San Antonio Abad de Cusco, Profesor Principal del Departamento Académico de Historia de la Escuela Profesional de Historia. E-mail: eleazar.crucinta@unsaac.edu.pe 
innegable repercusión que tuvo en las subsiguientes revoluciones, que a partir de este inicio Túpac Amarista, desembocaron con fuerza en la definitiva y verdadera independencia, en contexto eminentemente nacionalista, porque el holocausto de este líder, en lugar de haber generado desánimo libertario - como creyeron los españoles - repercutió con gran fuerza la continuidad de la lucha emancipadora y libertaria, porque gracias al sacrificio de Túpac Amaru, trocaron el subliminal respeto, a los españoles, en irreverencia, debido a la toma de conciencia en todos los estratos sociales y

"En la madrugada del 3 de agosto de 1814, una multitud de gente armada, entre ellos soldados, tomó el cuartel en el que se encontraban presos Vicente Angulo, Gabriel Béjar, Manuel Hurtado de Mendoza, entre otros."

es así que los criollos proponen alianzas anticoloniales. Antiguos criollos y mestizos afincados en el frente realista, se hacen revolucionarios; Mateo Pumacahua y los propios hermanos Angulo y muchos otros, durante el siglo XIX protagonizan insurrecciones hasta la llamada independencia peruana de 1821 .

1814, para la historia peruana debe significar "El Año del Orgullo Nacional y del más Profundo Nacionalismo", debido a la insurrección eminentemente nacionalista, que partió del Cusco con propuesta eminentemente nacionalista, donde los peruanos que al protagonizar esta gesta libertaria, sacudieron las estructuras colonialistas impuestas por y desde España. Por ello, proponemos conmemorar, este año, con gran patriotismo los festejos del Bicentenario de la Verdadera Independencia Peruana, porque la rebelión del Cusco, fue la empresa que tuvo el atributo de su irrefutable autonomía en la emancipación del yugo español, que llegó a abarcar una gran parte del virreinato del Perú.

Como bien se sabe esta gesta se originó el 03 de agosto de 1814 y finalizó en 1815, que llegó movilizar una gran parte del sur del virreinato del Perú, con frecuentes batallas armadas y obviamente con respuestas políticas, a la dominación colonial española, por ello, hacemos un llamado a los nacionalistas de hoy, reivindicar este Año del Bicentenario, que fue el verdadero acontecimiento que generó la independencia peruana.

Nuestros antepasados dieron respuestas nacionalistas a la opresión española, los de hoy, debemos dar respuestas nacionales a este tan magno acontecimiento, que rememoramos y que lamentablemente, está siendo preterida —a propósito? - del calendario cívico patriótico nacional.

No es posible olvidar, que ese año, el Cusco se encontraba completamente agitado políticamente, es así que, el conflicto que comentamos, se inició con confrontaciones política, entre el Cabildo Constitucional pro criollo, y la Real Audiencia del Cusco pro peninsular. A raíz de esos enfrentamientos, encarcelaron a los hermanos, Mariano, José, Juan y Vicente, Angulo Torres, sin embargo, es necesario esclarecer que, el primer intento de insurrección, fue planeado para el 9 de octubre de 1813, donde se exigía al presidente de la Audiencia del Cusco, la aplicación de la constitución liberal; este plan falló, porque fueron delatados por Mariano Zubizarreta, razón por la que los 
hermanos Angulo, Béjar y Carbajal, fueron arrestados; sin embargo, los insurrectos ya tenían planeado otro segundo intento, que se debió haberse cumplido el 5 de noviembre de 1813 , pero fueron encarcelados, porque Mariano Arriaga, los delató.

En la madrugada del 3 de agosto de 1814, una multitud de gente armada, entre ellos soldados, tomó el cuartel en el que se encontraban presos Vicente Angulo, Gabriel Béjar, Manuel Hurtado de Mendoza, entre otros oficiales del ejército real, acusados de infidencia. Ese acontecimiento daría inicio a la revolución del Cusco de 1814, con la siguiente proclama:

“Cuzqueños (...) todos sois uno e iguales (...), empezad ya a operar con denuedo hollando imperiosamente las leyes bárbaras de España, fundaos sólo en la necesidad, en la razón y la justicia, y sean éstas el timón donde gobernéis a un pueblo que no reconoce autoridad alguna extranjera".

Los insurrectos no improvisaron su gesta, existió alianzas de clases es así que, contaban con el apoyo del cacique de Chincheros el Brigadier Mateo Pumacahua, quien gozaba de gran prestigio entre los aborígenes, sin embargo, este personaje participo activamente a favor de la monarquía española y en contra de la rebelión de José Gabriel Túpac Amaru, fue comandante de los indígenas realistas en la batalla de Guaqui. Cambió su postura, movido por la imposición del virrey Abascal, al no garantizar el cumplimiento de la Constitución de Cádiz de 1812, en el virreinato del Perú. Las respuestas no solo fueron armadas sino que también políticas, así se demuestra en la respuesta de José Angulo al Virrey Fernando de Abascal y Sousa:

"Ved virrey (...) si (...) según es vuestra fe pública, os ponéis en la triste situación de tratarnos como enemigos, entonces experimentaréis nuestro justo rigor, vos y vuestros cómplices. Si, despachad tropas al pasto de nuestra venganza, nosotros os avisamos que no pasarán de cuatro mil fogueados valientes militares (...), que contrarrestarán con diez mil que vengan”.

El 8 de septiembre de 1814, en la catedral del Cuzco, con la bendición del obispo José Pérez y Armendáriz, se rindió culto solemne a una nueva bandera, con franjas transversales azul y blanco, que muy bien pudo haber sido la primera de una nueva nación y república naciente. En este acto, con el auspicio del Cabildo, se llegó a formar la Junta de Gobierno, invitando ponerse al frente de la rebelión, al cacique, el brigadier de los ejércitos reales Mateo Pumacahua; José Angulo asumió el título de Capitán General de las Armas de la Patria, rango más alto de la revolución. Vicente Angulo, fue investido con el grado de brigadier; Mariano Angulo, asumió la comandancia general del Cuzco con el grado de coronel; El religioso Juan Angulo, ofició de consejero y posiblemente de secretario de José Angulo. En ese constituido ejército patriota, se formaron tres secciones para entrar a las beligerancias armadas que movilizaron casi todo el sur del virreinato peruano.

- La primera sección del ejército patriota marchó al Alto Perú tuvo como jefes al cura Idelfonso Muñecas y José León Pinelo. Logró tomar La Paz, pero el ejército realista lo derrotó en la batalla de Chacaltaya.

- La segunda sección del ejército fue enviado a Huamanga, liderado por Manuel Hurtado de Mendoza, secundado por Mariano Angulo y José Béjar. Logró tomar Huamanga, pero poco después fue derrotado por los españoles en las batallas de Huanta y Matará.

- La tercera sección del ejército que fue a Arequipa estuvo al mando de Mateo 
Pumacahua, secundado por Vicente Angulo. Ganó la batalla de Apacheta y entró a la Ciudad Blanca. Pero ante la cercanía del ejército español del general Juan Ramírez, Pumacahua le salió al frente, siendo derrotado en la decisiva batalla de Umachiri, en el que fue fusilado el poeta patriota Mariano Melgar.

Este gran movimiento libertario, movilizo gran cantidad de gente y de distintas condiciones sociales, porque fue esencialmente separatista y sobre todo nacionalista; estuvieron presentes criollos, mestizos, clérigos, comerciantes, funcionarios y la gran masa de aborígenes andinos que ofrendaron sus vidas, en las distintas batallas que se dieron. Este movimiento de haber triunfado, sin duda alguna habría incoado la construcción de una república mixta y participativa con los distintos sectores y clases sociales existentes en el Perú, con gran preeminencia de andinos y de hecho totalmente distinto al 1821, con clara presencia criolla y completamente centralista; por ello, debemos reflexionar sobre ese fracaso de intento nacionalista revolucionario, por la falta de una adecuada cohesión de los integrantes, con la población, tal es el caso que, estos, tanto a los revolucionarios separatistas, como a los realistas españoles, los pobladores les juraron fidelidad, como lo ocurrido en Arequipa; porque siguiendo su existencialista lógica, los pobladores buscaban salvaguardar sus intereses, sobre todo económicos, fuera del contexto ideo político existente.

Este bicentenario debe servir para reflexionar, sobre este contexto político, para la construcción nacional, donde todo intento de cambio, reforma, tiene que contar con la necesaria participación de los integrantes de la nación, porque si no obra así, los discursos no conmueven no satisfacen las expectativas de la población, que en vez de unificar se hace disolvente, razón por la que desde estas entrañas del País - Cusco- ponemos en debate nacional, este acontecimiento histórico, porque no se debe soslayar, este acontecimiento, que si bien es cierto, no lograron "finiquitar" - entre comillas-

sus fines, consiguieron generar con creses, una conciencia nacional, y es por ello que llamamos a la población a festejar este verdadero bicentenario de la libertad peruana que tuvo sus orígenes en este Cusco Inmortal. Gloria eterna a las miles de vidas que ofrendaron en 1814 encabezados por los hermanos Angulo y Mateo Pumacahua creyentes en La libertad y la Construcción Nacional.

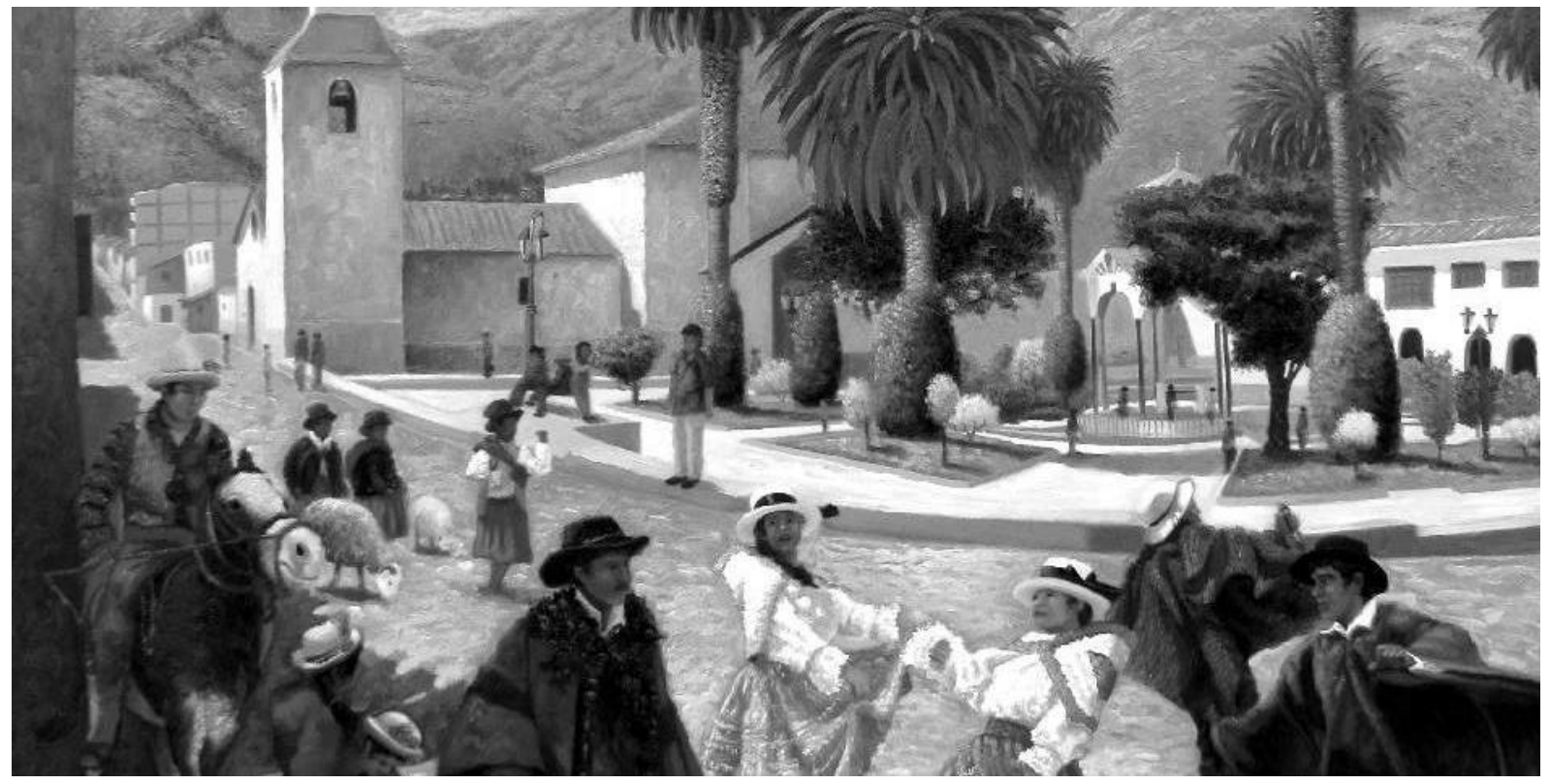


